\title{
Application of Electronic Commerce in International Trade
}

\author{
Ting ZHANG ${ }^{1, a}$ \\ ${ }^{1}$ Jiangxi college of foreign studies, NanChang 330099, China \\ azhangtingjx@163.com
}

Keywords: Electronic Commerce; International Trade; Foreign Trade Enterprise; Information

\begin{abstract}
As a new business mode of operation of electronic data exchange as the main content, e-commerce to break time and space constraints! Accelerated business cycles and efficient use of limited resources, reduce costs, increase profits, enhance the international competitiveness of enterprises. Thus, e-commerce is set off in international trade in the field of a new revolution. Its use, to expand the space and an area of international trade, shorten the distance and time of international trade, simplify the procedures and processes of international trade, international trade globalization, intelligent, paperless and simplified to achieve a epoch-making profound changes.
\end{abstract}

\section{Electronic commerce}

\section{Concept of e-commerce}

E-commerce is a wide means and scope that involves in a wide range of business activity. With the rapid development of computer network that takes information technology as the core, and the Internet and universal application of global e-commerce has become a new direction of development of network technology. The operation of e-commerce is a dynamic process, which involves the entire business process of information exchange, sale, payment, transport. Currently for e-commerce, has not yet formed a unified view. [1]Many experts and scholars try to define the connotation and extension of e-commerce from different angles.

According to World Trade Organization, e-commerce can be simply defined as the telecommunications networks of production, advertising, sales and distribution. Organization for Economic Co-operation and Development (OCED) pointed that e-commerce generally refers to commercial transactions online digital processing and transmission-based organizations and individuals, where the network can be either an open network such as the Internet, may be able coupled to the network via a gateway open a closed network, the information transmitted, including files, sound and images.

From the above description about different aspects of e-commerce, we can know that on the one hand the international organizations and national governments put emphasis on e-commerce, on the other hand it also can be seen that the definition of e-commerce is no a definitive conclusion. After summarizing all these ideas, this paper considered e-commerce as the information technology-based business activities, including production, circulation, distribution, exchange and consumption and other aspects of linking production and electronic information processing all active consumption.

\section{Competitive advantages of e-commerce}

As a new business situation, e-commerce greatly improved the effectiveness and efficiency of traditional business activities. Compared with the traditional business activities, it has the following competitive advantages:

\section{1) Reduce transaction costs}

First, the network marketing companies can improve sales efficiency and reduce marketing costs. According to statistics, Internet advertising can increase sales 10 -fold, while its cost is $1 / 10$ of traditional advertising; second, e-commerce can reduce procurement cost, because by means of Internet Company, people can seek the best price supplier in the global market, and working with suppliers of information can reduce intermediate links due to the loss caused by inaccurate information. [2]Our data show that application of EDI can save companies $5 \%$ to $10 \%$ of the purchase cost. 


\section{2) Reduce inventory}

To cope with the vagaries of the market demand, enterprises have to maintain a certain inventory products and raw materials. The root cause of inventory is poor information; information technology-based e-commerce business decisions can change the information inaccurate and not timely issues. It can be delivered via Internet market demand for enterprise decision-making production, while corporate demand information can be passed immediately to the supplier in a timely supplement supply in order to achieve cost inventory management.

\section{3) Shorten the production cycle}

Production is the collaborate results of many companies, so the design, development and production and sales of products may involve a number of associated companies, e-commerce can change the a phased closure of cooperation in the past to parallel mode, thereby minimizing unnecessary waiting time because the information close.

\section{4) Increase opportunities}

Traditional trading is constrained by time and space, while the Internet-based e-commerce is 24 hours - the global operation, the Internet business can be carried out beyond the market range traditional marketing and advertising promotions that reach.

\section{Applications of e-commerce in international trade}

E-commerce is an international trade tool innovation, which has increasingly shown its important role in global production in recent years. Companies involved in the international market, marketing and e-commerce companies have developed ways for global business.

International Trade E-commerce is the whole process of using modern communication technology, computer technology and network technology, electronic data transmission from the complete establishment of trade relations, commercial negotiations, and electronic contract to charter, booking, customs declaration, and inspection; apply for permits, quotas and payment settlement transactions. Due to its significant functional advantage of the huge economic and social role in promoting economic globalization, international trade e-commerce show strong vitality, and is changing the traditional international trade business ideas, business model and management work.[3]

\section{Essence of the combination of e-commerce and international trade}

As economic globalization intensifies and depth, more and more products are imported from outside the country, whereby importers and exporters engaged in international trade opportunities will also be more attractive. One of the main reasons that drive this rapid development of international trade is the mergence of the Internet and e-commerce, because through which new mode of operation, time, cost and effort are saved. However, application of e-commerce to international trade is not simply imagined by the suppliers to establish a website for your company, the world's importers will be able to find the vendor's product, then issue a query, inquiry, and so on until the contract requires that the sample, arrange shipping, payment loan so simple and so on. In international trade, importers and exporters have their own independent business purpose. Only when the intent of the parties organically linked, trade could be expanded. Similarly, the use of the Internet and e-commerce international trade process optimization must also be independent importers and exporters over the Internet for commercial purposes, the use of new technology, software, services and supporting processes to be connected to each other, so as to enable both sides reach their goal. In general, importers hope to find the most suitable suppliers through the Internet for the procurement of goods; compare and evaluate product features and the ability of the company's different suppliers; get the latest and most timely information of providers; realize the fastest and easiest way to search for the desired product procurement through importers accepted product classification and the industry's most common vocabulary. The exporter want to get more information about the company's products to these queries and query development into new businesses through e-commerce; to establish and maintain their own brands in the world to different geographic range; show the latest company and product information ready when needed; to keep abreast of market conditions, trends, importer demand, peer activities and so on. 


\section{Features of e-commerce}

\section{1) Support system of e-commerce}

E-commerce support system is modern information technology services. Modern information technology services mainly refer to the service system and computer and related means of communication. It includes computer software program design, construction information processing and transmission services, computer systems and network maintenance.

\section{2) Operation of space e-commerce}

The operation of e-commerce space is electronic virtual market. Electronic virtual market refers to a kind virtual form of the market where the producers, middlemen and consumers interact in a digital way. Electronic virtual market is the virtual market is the traditional market. [4] The so-called "digital economy" refers to the electronic virtual economic activity on the market in general term "electronic virtual market." E-commerce is the broad sense of the operating space.

\section{3) Market range of e-commerce}

E-commerce market size is global market. E-commerce market and the traditional market is different as the traditional market is restricted by borders, international commercial exchange of products or services activities largely intervened directly by government. However, from essentials to the point of view downright of e-commerce market range is global market.

\section{Applications of e-business in international trade}

As e-commerce was developed not long ago, although prospects for developing enterprises by taking advantage of electronic commerce in international trade is attractive, but still immature. At present, problems hinder the application of e-commerce is security issues, the legal regime, cultural conflicts and so on. However, from trend point of view, electronic commerce development for international trade is an inevitable choice of foreign trade enterprises in the 21st century. Currently application of e-commerce in foreign trade is mainly varied in three ways that are the EDI mode, Internet and Intranet mode.

\section{1)EDI way}

EDI (Electronic Date Interchange) refers to exchange business documents (including valuation orders, quotations, shippers, customs paragraph statement, etc.) between enterprises and enterprise in a standard electronic transmission data format exchange with each other through electronic communication, in order to reduce the data flow of the entire operating system of the time and space to eliminate barriers and reduce manual transcription errors generated business documents. EDI is mainly used in the document transport exports, compared with the traditional ordering and payment, it greatly save time and costs. EDI are generally used in a closed line network with a variety of conditions, such as user mostly has good credit guarantee, strict registration procedures, etc.. Therefore, it can better able to address security concerns, relatively better than the Internet.

\section{2)Internet way}

Internet is international network, which is the international Internet formed by connecting a large number of computer network through a certain standard. Internet was founded in 1969, the United States, followed by rapid development. Its nature also changed from the original research network to commercial networks. Commercial networks have emerged, specifically refers to the purchase of goods over the Internet, product marketing, information consulting, business to discuss a range of business and financial services transactions. Here consumers and businesses can make online shopping, online advertising and online legal services through the Internet, but because of the restrictions of laws and regulations, means of payment and others, the development of electronic commerce between consumers and businesses more slowly. It breaks through the traditional commercial production, the wholesale, retail and marketing model transfer process, truly realize small investment, low cost, high efficiency, so that the efficient allocation of social resources and maximum savings not only help enterprises to improve operational efficiency and competitiveness , but also conducive to the consumer at lower prices to get high quality products and services. As the Internet is of good network interoperability and low cost, it is not only can be adopted by large enterprises, SMEs can also use it, but problems like security is not yet resolved. 


\section{3)Intranet way}

Intranet is called the internet among enterprises. It uses Internet technology to connect the various branches and management departments within the enterprise to achieve the in-house information exchange and sharing. Intranet is not based on geographical division, but the enterprise-wide, that is, branches all over the world of the companies can share resources through intranet. [5] In Intranet, the confidential business information protected by a firewall security technology, only internal staff has access to confidential information, suppliers and customers and other outsiders can only enter the intranet under license conditions.

Intranet generally have two effects: first, provide enterprises with information infrastructure in the global business and make the enterprise employees around the world can communicate with each other, and office automation and paperless; second, work as an auxiliary sales channels, strengthen sales staff to contact the customer, the customer can access based on certain permissions intranet to help customers understand the product information to improve product sales. Different types of enterprises adopt different kind of e-commerce. Large-scale foreign trade enterprises use Intranet + Internet-based EDI more, while SMEs use the Internet for international trade. Foreign firms tend to use extranet. Enterprises focus both on production and trade tend to put emphasis on both intranet and extranet.

\section{Problems China's foreign trade enterprise e-commerce application process face}

Although the Chinese government has attached great importance to foreign trade enterprise e-business applications, and also achieved some success, but in the process $f$ the application of e-commerce of China's foreign trade enterprises still exist many problems.

Imbalance of application and development among the application of e-commerce in foreign trade enterprises

Because of the unbalanced economic development in different regions of China, e-commerce application and development of foreign trade enterprises is uneven. Higher levels of e-commerce development in Beijing, Shanghai, Shandong and Guangdong and other developed areas, the level of development of e-commerce in foreign trade enterprises was significantly much higher than the central and western regions, while China's central and western regions require much effort to develop e-commerce, especially use e-commerce development of international trade in the foreign trade enterprises to stimulate economic development. In various areas of foreign trade enterprises, application and development of e-commerce there is imbalance.

Policy, legal environment need to be improved for foreign trade enterprises to develop e-commerce

Overall, China's information policy is not perfect, especially reflected in e-commerce, where the relevant policy is not clear, relevant laws, regulations and relevant standards are not yet established, coordinating cross-sector and inter-regional presence show big problems. Because foreign trade enterprises develop e-commerce involves many departments, industrial and commercial administration, customs, insurance, taxation, banking and different regions, countries which need to strengthen e-commerce law, policy building in order to promote the vigorous development of electronic commerce.

\section{Low utilization rate of e-commerce in foreign trade enterprises}

China's foreign trade enterprises have just begun not long ago to use electronic commerce for international trade, but the utilization rate is still very low. Foreign trade enterprise e-commerce site features are single, most use the Internet to deliver advertising, electronic catalogs, e-discovery, online commodities exchange information; few electronic transactions (electronic negotiation, order) use the Internet to conduct business negotiations, sign purchase contracts, exchange text and documents, transactions, little sound e-business applications throughout the international trade process. 


\section{Summary}

E-commerce is the mainstream of the way of foreign trade in the 21st century, which can be used in almost all sectors of import and export business, therefore bring many benefits. E-commerce can be adapted to expanded international trade markets, thus creating opportunities for foreign trade enterprises to reshape international competitive advantage. China's foreign trade enterprises should seize this rare opportunity, and enhance the international competitive advantage of enterprises through e-commerce applications.

\section{References}

[1] Huang Lijin, The economic impact of the network on international trade. Foreign trade: economy, international trade, 2010

[2] Zhao Liping, Electronic Commerce. Shanghai: Fudan University Press, 2011

[3] Sun Liyun, Yanchun Rong, International e-commerce and conventional international trade. Ppractices of international trade, 2011

[4] Gu Linfang, He Xinyu, E-commerce and the impact of China's foreign trade enterprises in strategic choice. Business Research, 2015

[5] Wang Jianguo, E-commerce development in the field of foreign trade. China Information Review, 2013 